\title{
Strategic Analysis of Financial Risks in the Conditions of the Existing Macroeconomic Dynamics
}

\author{
Arthur Panasyuk* , Mikhail Shatokhin, Sergei Kuleshov and Leonid Matyunin \\ Institute of World Civilizations, Moscow, Russian Federation
}

\begin{abstract}
The paper considers the theoretical and practical aspects of the analysis of financial risks in the context of the existing macroeconomic dynamics. The study describes the essence and main types of financial risks of business entities, which are actualized in a turbulent macroeconomic environment. The author proposes a methodological approach for conducting a strategic analysis of financial risks, which is based on their probabilistic assessment and quantitative substantiation of the impact force. Practical testing of the proposed methodology allows for a quantitative substantiation of the level of financial risks in the activities of an economic entity, which contributes to an increase in certainty in the mechanism of their management.
\end{abstract}

\section{Introduction}

One of the most relevant characteristics of the existing conditions for carrying out entrepreneurial activity of almost all categories of economic entities is the turbulence of the impact of environmental factors. The instability of the macroeconomic environment is caused by a wide range of factors, ranging from the patterns of the intra-systemic development of the national economy and ending with the negative impact of external economic sanctions. The main result of the presence of such a business environment is the formation of a wide range of financial risks. In the context of the foregoing, the key tasks of the management of business entities is to identify, identify and develop directions for minimizing financial risks $[1, \mathrm{p} .55]$. An important tool in the financial risk management system is their assessment, which should make it possible to clearly substantiate the potential threats of an event occurring, taking into account a certain degree of its probability. The most optimal solution to this problem is the use of quantitative and qualitative methods of management diagnostics, allowing for a comprehensive identification of financial risk.

The purpose of this study is to conduct a strategic analysis of the financial risks of business entities in the context of the existing macroeconomic dynamics. To achieve this goal, a certain list of tasks is solved in the work:

\footnotetext{
*Corresponding author: panas@rambler.ru
} 
- to reveal the essence and types of financial risks of economic entities in the conditions of the existing macroeconomic dynamics;

- to propose a methodology for strategic analysis of assessing the financial risks of economic entities based on the use of quantitative and qualitative methods;

- to carry out practical adaptation of the developed author's methodology for assessing financial risks based on the materials of the financial statements of a particular economic entity.

In the process of carrying out this study, the methods of financial analysis and expert assessment, as well as selective observation, grouping and scientific synthesis were used primarily.

The practical significance of the proposed author's methodology lies in the quantitative assessment of the aggregate financial risk of an economic entity, which makes it possible to develop a set of adequate measures to manage it, taking into account the specifics of the current macroeconomic environment.

\section{Results and discussion}

The basis for building an effective financial risk management system, first of all, should be based on the understanding that their presence is an objective fact of entrepreneurial activity. Thus, we can make a general conclusion that financial risks will always exist in the process of organizing a business. At the same time, the likelihood of their occurrence fluctuates significantly both under the influence of internal and under the influence of external factors. In view of their specificity, internal factors are subjective and are largely determined by the specifics of managing business processes in each individual economic entity. The strength of the impact of external factors for most of the subjects of the national economic system is determined by the laws of the existing macroeconomic dynamics. At the moment, we can unequivocally state an increase in the likelihood of the onset of financial risks due to unfavorable macroeconomic dynamics [4, p.13]. The main factors contributing to an increase in the likelihood of financial risks occurrence include the following:

- lack of general stability of the domestic economic system;

- an increase in the pressure of the political factor on the formation of the investment climate and the stabilization of commercial relations;

- the negative impact of the pandemic caused by exposure to covid-19;

- active pressure on financial processes from external economic sanctions;

- a significant increase in the volatility of financial markets.

The presented list of factors has a radical impact on the level of financial risks of economic entities of the domestic economic system.

In the most general form, financial risks are unfavorable events, the occurrence of which is expected with a certain degree of probability and which generate threats to the financial and economic activities of an economic entity [3, p.227]. The deterioration of macroeconomic dynamics significantly increases the relevance of management activities in the field of financial risk management. Important features of financial risks in terms of their identification and management are:

- the presence of a stable connection with the economic and economic activity of the entity, since the significance of a particular financial risk can be determined taking into account the amount of economic damage caused to it;

- the relevance of continuous monitoring of the amount of financial risk due to its variability depending on the impact of a wide range of factors; 
- the presence of the possibility of formalizing the level of financial risk based on the use of statistical parameters and quantitative models, since there is a stable relationship with the indicators of economic and economic activity [5, p.425].

The classification of financial risks is important not only for their identification, but also for the choice of management methods, since each type of financial risk uses its own individual methods of diagnosis and minimization [2, p. 233]. Figure 1 shows the general classification of financial risks in the author's interpretation.

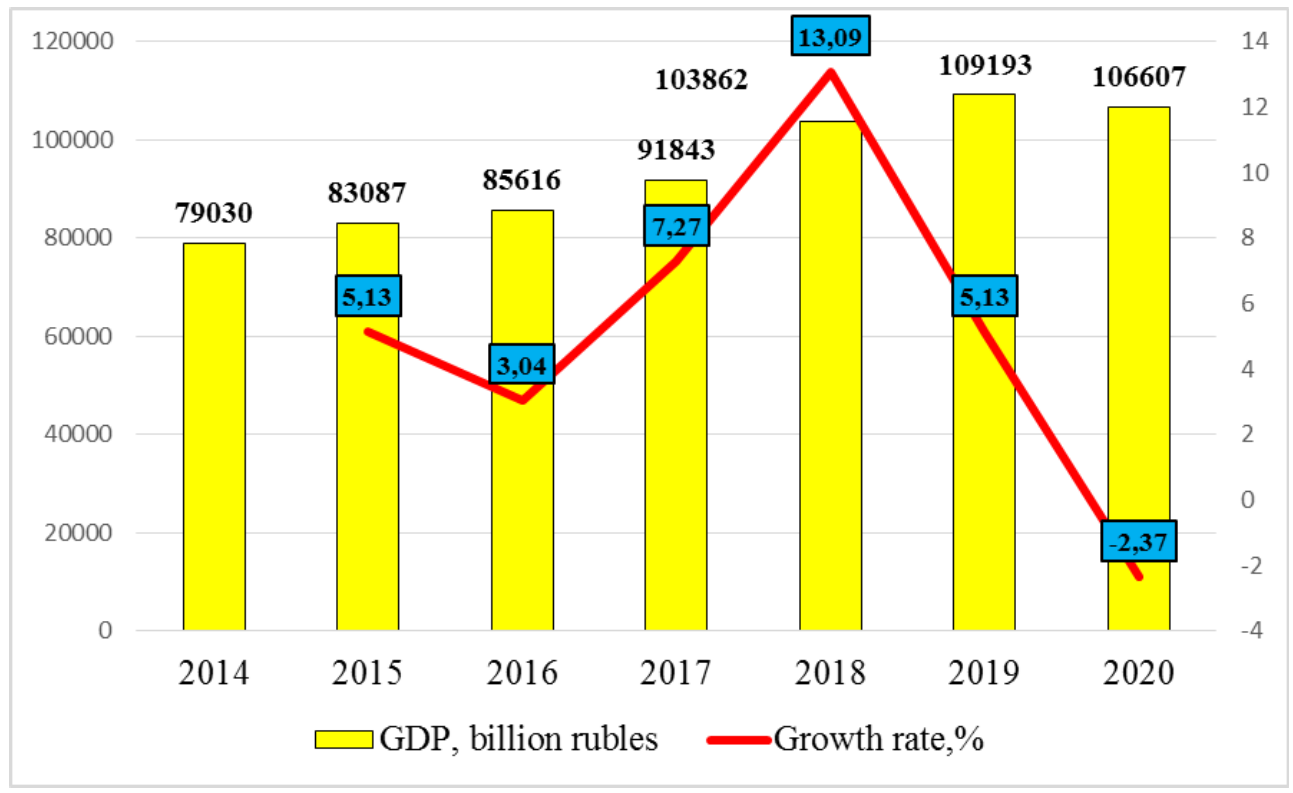

Fig. 1. General classification of financial risks

Taking into account the material presented in Figure 1, we can conclude that the level of their consistency is an important criterion for classifying risks. At the same time, the category of consistency is largely correlated with the level of impact on financial risks from the management of an economic entity:

- systemic risks are almost completely objective in nature and are due to the laws of the functioning of the financial system as a whole. The likelihood of these risks occurring minimally depends on the behavior of the management of an economic entity;

- non-systemic financial risks have a certain level of correlation with management decisions made in the enterprise management system. Mistakes in the choice of areas of investment activity, a decrease in the efficiency of asset management, a suboptimal capital structure - all this can lead to an increase in the likelihood of financial risks.

In accordance with the tasks set in the work, the author has developed a methodology for the quantitative assessment of non-systemic financial risks. The proposed approach is based on elements of strategic SNW analysis. When constructing a methodology for strategic SNW analysis, a quantitative assessment of the total financial risk of an economic entity will be given. At the same time, the aggregate financial risk of an economic entity will include the following types of non-systemic risks:

- risk of declining financial stability - the risk of increasing dependence on external sources of financing up to the complete loss of financial independence. The reason for the increase in the likelihood of the risk of a decrease in financial stability is the formation of 
an irrational capital structure and an increase in the share of borrowed funds in the structure of sources of financing activities;

- risk of loss of solvency - the risk of a decrease in the payment capacity of an economic entity due to the lack of liquid assets to cover the amount of short-term liabilities. This risk is formed as a result of a decrease in the size of the most liquid and liquid assets, as well as in the process of an increase in the amount of short-term liabilities;

- credit risk - the risk of refusal to obtain borrowed funds to finance production, economic and commercial activities from specialized credit institutions.

In table 1, we present the methodology for distributing the degree of influence of financial risk on the activities of an economic entity in the framework of strategic SNW analysis.

Table 1. Methodology for the distribution of the degree of influence of financial risk on the activities of an economic entity in the framework of strategic SNW analysis

\begin{tabular}{|c|c|c|c|c|c|c|c|c|}
\hline \multirow{3}{*}{$\begin{array}{l}\text { Name of the } \\
\text { indicator of } \\
\text { aggregate } \\
\text { financial risk }\end{array}$} & \multicolumn{6}{|c|}{ Impact of risk (from 1 to 3 ) * } & \multirow{3}{*}{$\begin{array}{c}\text { Probability } \\
\text { of risk } \\
\text { occurrence } \\
\text { (from } 0 \text { to } \\
1 \text { ) }\end{array}$} & \multirow{3}{*}{$\begin{array}{l}\text { Share of } \\
\text { risk in total } \\
\text { financial } \\
\text { risk (from } 0 \\
\text { to } 1 \text { ) }\end{array}$} \\
\hline & \multicolumn{3}{|c|}{$\begin{array}{l}\text { Threat (-) Opportunity } \\
(+)\end{array}$} & \multicolumn{3}{|c|}{ Opportunity $(+)$} & & \\
\hline & -3 & -2 & -1 & 1 & 2 & 3 & & \\
\hline Autonomy ratio & $<0$ & $0-0,2$ & $0,2-0,3$ & $\begin{array}{c}0,3- \\
0,5\end{array}$ & $\begin{array}{c}0,5- \\
0,7\end{array}$ & $>0,7$ & E & 0,25 \\
\hline $\begin{array}{c}\text { Financial } \\
\text { stability ratio }\end{array}$ & $<0$ & $0-0,2$ & $0,2-0,4$ & $\begin{array}{c}0,4- \\
0,6\end{array}$ & $\begin{array}{c}0,6- \\
0,8\end{array}$ & $>0,8$ & $\mathrm{E}$ & 0,15 \\
\hline $\begin{array}{l}\text { Coefficient of } \\
\text { provision with } \\
\text { own circulating } \\
\text { assets } \\
\end{array}$ & $<0$ & $0-0,1$ & $0,1-0,2$ & $\begin{array}{c}0,2- \\
0,3\end{array}$ & $\begin{array}{c}0,3- \\
0,4\end{array}$ & $>0,4$ & $\mathrm{E}$ & 0,1 \\
\hline $\begin{array}{c}\text { Absolute } \\
\text { liquidity ratio }\end{array}$ & $<0$ & $\begin{array}{c}0- \\
0,05\end{array}$ & $\begin{array}{c}0,05- \\
0,1\end{array}$ & $\begin{array}{l}0,1- \\
0,2 \\
\end{array}$ & $\begin{array}{c}0,2- \\
0,3 \\
\end{array}$ & $>0,3$ & E & 0,1 \\
\hline Quick ratio & $<0$ & $0-0,2$ & $0,2-0,5$ & $\begin{array}{c}0,5- \\
0,7 \\
\end{array}$ & $\begin{array}{c}0,7- \\
0,9 \\
\end{array}$ & $>0,9$ & E & 0,2 \\
\hline $\begin{array}{c}\text { Current liquidity } \\
\text { ratio } \\
\end{array}$ & $<0$ & $0-0,3$ & $0,3-0,5$ & $0,5-1$ & $1-2$ & $>2$ & E & 0,2 \\
\hline Total & - & - & - & - & - & - & - & 1 \\
\hline
\end{tabular}

Note: the assessment of the degree of impact was carried out according to a point system from 1 to 3 , where 1 - the influence of the factor is insignificant, 2 - moderate, 3 - critical / high. E - expert assessment of the author

For the purpose of practical testing of the presented methodology, in Table 2, we present the main indicators of total financial risk, calculated on the basis of the financial statements of PJSC Novolipetsk Metallurgical Plant [6].

Table 2. Indicators of the aggregate financial risk of PJSC "Novolipetsk Metallurgical Plant" *

\begin{tabular}{|c|c|c|c|c|}
\hline Indicator name & 2018 & 2019 & 2020 & $\begin{array}{c}\text { Deviation 2020 from 2018, } \\
+/-\end{array}$ \\
\hline Autonomy ratio & 0,581 & 0,557 & 0,449 & $-0,132$ \\
\hline $\begin{array}{c}\text { Financial stability ratio } \\
\text { Coefficient of provision with own circulating } \\
\text { assets }\end{array}$ & 0,745 & 0,775 & 0,739 & $-0,007$ \\
\hline Absolute liquidity ratio & 0,413 & 0,404 & 0,236 & $-0,177$ \\
\hline Quick ratio & 1,285 & 1,207 & 0,917 & $-0,037$ \\
\hline Current liquidity ratio & 1,703 & 1,678 & 1,309 & $-0,367$ \\
\hline
\end{tabular}

* Source: calculated on the basis of data from the annual financial statements of PJSC

"Novolipetsk Metallurgical Plant" 
Based on the information base presented in Table 2, it can be concluded that most of the indicators of the total financial risk in the activities of PJSC Novolipetsk Iron and Steel Works within the studied time period have a tendency to decrease. The presence of this trend allows us to make a superficial conclusion about the increase in the level of total financial risk in the activities of this metallurgical enterprise. In the context of the above, first of all, it is worth noting a decrease in 2020 compared to 2018 in the value of the equity ratio by 0.132 , a decrease in the quick liquidity ratio by 0.367 and the current liquidity ratio by 0.394 .

The results of practical testing of the author's methodology for assessing the value of the aggregate financial risk of an economic entity are presented in Table 3.

Table 3. Assessment of the value of the aggregate financial risk in the activities of PJSC "Novolipetsk Metallurgical Plant"

\begin{tabular}{|c|c|c|c|c|c|c|c|c|c|c|}
\hline \multirow{2}{*}{$\begin{array}{l}\text { Name of the } \\
\text { indicator of } \\
\text { aggregate } \\
\text { financial } \\
\text { risk }\end{array}$} & \multicolumn{3}{|c|}{$\begin{array}{l}\text { Impact of risk (1 to } \\
3 \text { ). Threat (-). }\end{array}$} & \multicolumn{3}{|c|}{$\begin{array}{c}\text { Opportunity }(+) \\
\text { Probability of risk } \\
\text { occurrence (from } 0 \text { to } \\
\text { 1) }\end{array}$} & \multirow{2}{*}{$\begin{array}{l}\text { Share of } \\
\text { risk in } \\
\text { total } \\
\text { financial } \\
\text { risk (from } \\
0 \text { to } 1 \text { ) }\end{array}$} & \multicolumn{3}{|c|}{$\begin{array}{l}\text { Integral assessment of } \\
\text { the probability of total } \\
\text { financial risk }\end{array}$} \\
\hline & 2018 & 2019 & 2020 & 2018 & 2019 & 2020 & & 2018 & 2019 & 2020 \\
\hline $\begin{array}{c}\text { Autonomy } \\
\text { ratio }\end{array}$ & 2 & 2 & 1 & 0,5 & 0,5 & 0,6 & 0,25 & 0,25 & 0,25 & 0,1 \\
\hline $\begin{array}{c}\text { Financial } \\
\text { stability } \\
\text { ratio } \\
\end{array}$ & 2 & 2 & 2 & 0,4 & 0,4 & 0,4 & 0,15 & 0,18 & 0,18 & 0,18 \\
\hline $\begin{array}{l}\text { Coefficient } \\
\text { of provision } \\
\text { with own } \\
\text { circulating } \\
\text { assets }\end{array}$ & 3 & 3 & 1 & 0,3 & 0,3 & 0,5 & 0,1 & 0,21 & 0,21 & 0,05 \\
\hline $\begin{array}{l}\text { Absolute } \\
\text { liquidity } \\
\text { ratio }\end{array}$ & 3 & 3 & 3 & 0,3 & 0,3 & 0,3 & 0,1 & 0,21 & 0,21 & 0,21 \\
\hline Quick ratio & 3 & 3 & 3 & 0,2 & 0,2 & 0,3 & 0,2 & 0,48 & 0,48 & 0,42 \\
\hline $\begin{array}{l}\text { Current } \\
\text { liquidity } \\
\text { ratio }\end{array}$ & 2 & 2 & 2 & 0,3 & 0,3 & 0,4 & 0,2 & 0,28 & 0,28 & 0,24 \\
\hline Total & & & & & & - & 1 & 1,61 & 1,61 & 1,2 \\
\hline
\end{tabular}

Summarizing what has been said, it can be noted that the higher the value of the integral assessment of the total financial risk, the lower the likelihood of its occurrence.

\section{Conclusion}

The performed calculations allow us to conclude that in PJSC "Novolipetsk Metallurgical Plant" during the studied time period there is an increase in the likelihood of the occurrence of the aggregate financial risk. This fact is confirmed by a decrease in the indicator of the integral assessment of the total financial risk in 2020 compared to 2018 by 0.41 . A negative impact on the growth of the aggregate financial risk in the activities of PJSC "Novolipetsk Metallurgical Plant" had a decrease in the share of equity capital in the structure of sources of financing of the enterprise, as well as a decrease in the level of coverage of short-term liabilities by working capital. In general, according to the results of the research carried out, it can be noted that a quantitative assessment of the probability of the occurrence of financial risk is important for the formation of an effective mechanism for managing it in 
the management system of an economic entity. The method of quantitative assessment of the probability of the aggregate financial risk proposed in the work by the author is universal in nature, since it can be adapted to the activities of almost any economic entity. The high level of verification of the calculations carried out within the framework of this methodology is justified by the reliability of the information base disclosed in the materials of the financial statements. The proposed method can be used in the practical activities of the management of an economic entity to remove uncertainty in the management of financial risks.

\section{References}

1. T.V. Babaev, A.A. Kocharova Financial risks of a commercial organization and ways to minimize them. Economy and business: theory and practice. 5-1, 54-57. (2019)

2. E.V. Vylegzhanina, I.S. Grigoryan Financial risks of an enterprise and ways to minimize them. International Journal of the Humanities and Natural Sciences. 1-1, 231-234 (2019)

3. E.S. Zinovieva at ets Strategic management of financial risks and methods of their assessment Innovative economy: prospects for development and improvement. 2 (36). 226-233 (2019)

4. M.A. Mingaleeva Financial risk management. StudNet. 1, 10-17 (2021)

5. L.A. Terentyeva at ets Financial risks of companies: essence, classification, problems of reduction. Innovative Economy: Prospects for Development and Improvement. 2 (36), 423-429 (2019)

6. Official site of PJSC "Novolipetsk Metallurgical Plant". - URL: https://nlmk.com/ru/ 